\title{
WPS2609
}

\section{Financial Dependence and International Trade}

\author{
Thorsten Beck ${ }^{1}$ \\ The World Bank
}

\begin{abstract}
${ }^{1}$ Helpful comments from Marianne Baxter, Robert Cull, Bob King, Ross Levine, Colin $\mathrm{Xu}$, two anonymous referees and seminar participants at the University of Virginia, the World Bank, the University of California at Davis and the Annual Meeting of the Southern Economic Association are gratefully acknowledged. The usual disclaimer applies. The findings, interpretations and conclusions in this paper are entirely those of the author and do not necessarily represent the view of the World Bank, its Executive Directors, or the countries they represent. JEL classification: F1, O16; Keywords: International Trade, External Finance, Financial Development. Address: The World Bank, 1818 H Street, N.W., Washington D.C. 20433. Ph: (202) 473-3215, Fax: (202) 522-1155, e-mail: tbeck@worldbank.org
\end{abstract}




\section{Financial Dependence and International Trade}

Does financial development translate into a comparative advantage in industries that use more external finance? We use industry-level data on firms' dependence on external finance for 36 industries and 56 countries to examine this question. We show that countries with better-developed financial systems have higher export shares and trade balances in industries that use more external finance. These results are robust to the use of alternative mea-

sures of external dependence and financial development and are not due to reverse causality or simultaneity bias. 


\section{Introduction}

The international trade literature focuses on factor endowments, technology and scale economies as sources of comparative advantage and therefore determinants of trade flows between countries. Theory, however, also suggest that the level of financial development may importantly influence the pattern of international trade flows. Kletzer and Bardhan (1987) augment the Heckscher-Ohlin trade model by incorporating a financial sector and show that financial sector development gives countries a comparative advantage in industries that rely more on external financing. This paper explores empirically whether the level of financial sector development constitutes a source of comparative advantage and explains the variance of the trade structure across countries. Specifically, we assess whether a high level of financial development translates into a comparative advantage in industries that rely more heavily on external finance.

This is an interesting question for several reasons. First, if we find that the level of financial development does have an effect on the industrial structure of the trade balance, this emphasizes the importance of financial sector development for economic development beyond its positive impact on economic growth and therefore increases the priority that financial sector reforms should have on policy makers' agendas.

Second, if the level of financial development is a determinant of the structure of the trade balance, this has implications for policy reforms in both the financial and the trade sector. On the one hand, a reform of the financial sector that raises the level of external finance available to firms in an economy, might have an impact on the industrial structure of this country's exports. On the other hand, the effect of trade reforms on the industrial structure of the trade balance might depend on the level of external finance available in the economy.

While there are certainly a variety of channels through which the level of financial sector development can translate into a comparative advantage we concentrate on just one. Specifically we focus on the financial sector's 
function to channel funds from savers to firms. By economizing on the costs of acquiring and processing information about firms and monitoring managers, financial institutions and markets can help overcome the problems of moral hazard and adverse selection, thus reducing the cost of external finance for firms. Countries with better developed financial institutions and markets should therefore have a comparative advantage in industries that rely relatively more on external finance. ${ }^{1}$

To illustrate the test undertaken in this paper, consider Mexico and Korea, two middle-income developing countries that differ considerably in their level of financial development. Credit to the private sector by financial intermediaries as share of GDP was $12 \%$ for Mexico and $66 \%$ for Korea in the period 1980-89. Pottery is an industry that uses no external finance, whereas plastic products relies heavily on external finance. Whereas Mexico's trade balance in plastic goods was 0.05 percentage points lower than its trade balance in pottery in 1980-89, Korea's trade balance in plastic goods was 0.29 percentage points higher than its trade balance in pottery.

To test our hypothesis empirically we follow a technique proposed by Rajan and Zingales (1998). Rajan and Zingales (1998) show that industries that use more external finance grow faster in countries with a higher level of financial sector development. Using the methodology developed by Rajan and Zingales this paper explores whether the level of financial sector development has an impact on trade patterns across countries. Thus we do not re-assess whether different levels of financial development differently influence the growth of industries with greater or smaller financing needs. Instead, we test the hypothesis that economies with higher levels of financial development have higher export shares and trade balances in industries that use more external finance.

Using Rajan and Zingales' data on external dependence, we find robust evidence for our hypothesis that countries with better developed financial

\footnotetext{
${ }^{1}$ In the following we will use the terms external dependence, reliance and use of external finance interchangeably.
} 
systems have higher export shares and trade balances in industries that rely more heavily on external finance. Using different measures of financial development across countries and the reliance on external finance across industries, our results are consistent in indicating a large positive relationship of the interaction of external dependence and financial development with export shares and trade balances across industries and countries. These results are robust to the use of instrumental variables, thus controlling for simultaneity bias and possible reverse causality.

As an alternative test of our hypothesis we also consider a simplified variation of the factor-content studies of trade flows by Bowen, Leamer, and Sveikauskas (1987) and Trefler (1993, 1995). Specifically, we calculate the weighted average external dependence of a country's exports and trade balance and explore correlations between these measures and indicators of financial sector development.

The remainder of the paper is organized as follows. We first discuss the theoretical underpinnings of the link between financial development and the industrial structure of the trade balance in section 2 . In section 3 we present the econometric methodology. We then describe the data on external dependence, financial sector development and trade in section 4 . In section 5 we present our main results. In section 6 we explore the robustness of our findings and alternative explanations. Section 7 concludes.

\section{External Dependence, Comparative Advan- tage, and International Trade}

Classical models of international trade explain the comparative advantage of countries with differences in technology or endowments. ${ }^{2}$ Both the Ricardian and the Heckscher-Ohlin model, however, can be easily augmented to show the effect of financial sector development on international trade flows.

\footnotetext{
${ }^{2}$ For an overview see Jones (1984).
} 
Baldwin (1989) developed one of the first models, in which financial markets are a source of comparative advantage. In his two-country, two-sector and one-factor model, the demand for one of the goods is subject to demand shocks, while the other is not. He shows that in economies with better developed financial markets and therefore better possibilities to diversify risk stemming from the demand shocks, firms producing the risky good face lower risk premia and therefore lower marginal costs. Countries with better developed financial markets and therefore better diversification possibilities thus specialize in the risky good.

While Baldwin stresses the risk diversification function of financial markets, Kletzer and Bardhan (1987) focus on the role of financial institutions and markets in channeling external finance to industries that are in need of it. They present two international trade models in the Heckscher-Ohlin tradition with two countries, two sectors and two factors. While both sectors depend on land and labor, one sector also depends on external finance for working capital. They show that the country with a lower level of credit market restrictions specializes in the sector that uses external finance. The country with the higher level of credit market restrictions faces either a higher price of external finance or credit rationing and will therefore specialize in the sector that does not require working capital or external finance.

We can derive the link between financial development and international trade also in the context of a simple back-of-the-envelope extension of the Ricardian trade model. Assume an economy with two sectors - food and manufacturing. While firms in the food sector produce with an inherited technology, manufacturing firms need working capital to purchase the technology every period before the production process. Firms have available different technologies whose quality increases in their price. The available external funds for the working capital thus determine the quality of technology and therefore the labor productivity in manufacturing. If we assume that country 1 and country 2 only differ in the amount of external financing available to the manufacturing sector, this difference will drive comparative advantage 
and therefore trade flows. If country 1 has more external finance available than country 2 , it will have a comparative advantage in manufacturing and therefore export manufactured goods. Country 2, on the other hand, will have a comparative advantage in food and export food. ${ }^{3}$

Both the Kletzer and Bardhan and the augmented Ricardian model predict that countries with better developed financial sectors have a comparative advantage in industries with higher external financing needs. ${ }^{4}$ We should therefore observe that, holding other things constant, countries with better developed financial sectors have higher exports and trade balances in industries that rely more on external financing. To test this hypothesis, we therefore have to use trade flows on the industry level.

The relationship between the structure of the trade balance and financial sector development can also be derived from the recent literature on the link between financial development and economic growth. ${ }^{5}$ Financial intermediaries and markets arise to overcome the problems of moral hazard and adverse selection that drive a wedge between the price of external and internal finance. By decreasing the cost of external finance, financial intermediaries allow a higher return on capital and thus more investment opportunities realized, which in turn enhances economic growth. Industries that rely more heavily on external finance should profit more than proportionally from a higher level of financial development and therefore a lower cost of external finance. Rajan and Zingales (1998) find evidence that industries relying more heavily on external finance grow faster in countries with a better developed financial system.

\footnotetext{
${ }^{3}$ We can cast this also in the context of a formal model. Define $a_{c i}, c=1,2, i=1,2$ as country $c$ 's labor requirement per unit of output in sector $i$, where food is sector 1 and manufacturing sector 2 . If country 1 has more external finance available than country 2 , then $a_{12}<a_{22}$ and country 1 will export good 2 (manufacturing), while country 2 will export good 1 (food).

${ }^{4}$ To the best knowledge of the author, no empiricial study has been undertaken yet to explore the link between financial development and the structure of international trade flows.

${ }^{5}$ See Levine (1997) for an overview.
} 
If industries that rely more on external finance profit relatively more from a higher level of external finance, this should also affect the structure of the trade balance. As Rajan and Zingales note, countries with a higher level of financial development should have a comparative advantage in industries relying more on external finance and therefore higher exports shares and higher trade balances in these industries.

Many economists have argued that the development of the financial sector follows rather than leads the development of the real sector. In terms of our work, this would mean that the specialization of a country in specific industries creates the demand for a well-developed financial sector. An empirical test of the link between the interaction of financial development and external dependence and the structure of the trade balance therefore has to control for this possibility of reverse causality.

\section{The Econometric Model}

The hypothesis derived from the Kletzer and Bardhan (1987) model and the back-of-the-envelope extension of the Ricardian model, described in the previous section, is that economies with a higher level of financial development have higher export shares and trade balances in industries that rely more on external finance. We will run the following regression to empirically assess the relationship of the interaction of financial development and reliance on external finance with exports and trade balances.

$$
\begin{aligned}
y_{i, k}= & \sum_{j} \alpha_{j} \operatorname{COUNTRY_{j}}+\sum_{l} \beta_{l} I N D U S T R Y_{l} \\
& +\delta\left(E X T_{k} * F I N A N C E_{i}\right)+\epsilon_{i, k}
\end{aligned}
$$

where $y_{i, k}$ will be the ratio of exports or the trade balance to GDP in industry $k$ and country $i$ over the period 1980-89, COUNTRY $Y_{j}, j=1, \ldots, 56$ are country dummy variables, INDUSTRY $Y_{l}, l=1, \ldots, 36$ are industry dummy variables, $E X T_{k}$ is the external dependence for industry $k$ as measured for 
a sample of U.S. firms over the period 1980-89, FINANCE $E_{i}$ is the level of financial development for country $i$ and $\epsilon_{i, k}$ is the error term. All data are averaged over the period $1980-89 .^{6}$

We interact industry characteristics with country characteristics, in this case the reliance on external finance across industries and indicators of financial development across countries. The dummy variables for countries and industries control for country and industry specific effects that might determine the structure of the trade balance. ${ }^{7}$ We thus isolate the effect that the interaction of external dependence and financial development has on the exports and trade balances relative to country and industry averages. The coefficient of interest in equation (1) is $\delta$. If we find a positive coefficient on this interaction term, this can be interpreted as evidence in favor of our hypothesis. A negative or insignificant coefficient might signal the irrelevance of financial development for the structure of the trade balance. A significantly positive $\delta$ provides evidence in favor of the Kletzer and Bardhan model that countries with better developed financial systems have a comparative advantage in industries that use more external finance.

We will use the legal origin of countries as instrumental variables for the level of financial sector development to control for simultaneity bias and reverse causality. ${ }^{8}$ Previous research has shown that the legal origin of a country materially influences its legal treatment of creditors and shareholders, its accounting standards and the efficiency of contract enforcement, and thus the

\footnotetext{
${ }^{6}$ Both the trade indicators and FINANCE are included in logs, so that the results can be interpreted as elasticities. Since the data from the U.S. is used to calculate the dependence ratios, all U.S. observations are dropped from the regressions.

${ }^{7}$ By including country dummies in the regression we control for other determinants of industry export shares and trade balances, such as higher GDP growth or a smaller size of the economy. By including industry dummies we control for the fact that some industries might be more export-oriented than others, for reasons that are not related to financial development.

${ }^{8}$ The countries in our sample have either British, French, German or Scandinavian legal origin. Data are from La Porta, Lopez-de-Silanes, Shleifer and Vishny, henceforth LLSV (1999).
} 
efficiency of financial intermediaries and markets. ${ }^{9}$

As an alternative test of the Kletzer and Bardhan model, we will also consider a simplified variation of the empirical factor-content studies of international trade. The Heckscher-Ohlin-Vanek theorem states that countries export the commodity which uses intensively its relatively abundant resource. Similarly, the results of the Kletzer and Bardhan model can be stated as follows: countries with relatively high levels of financial development export the good whose production depends intensively on external finance. Bowen, Leamer, and Sveikauskas (1987) and Trefler $(1993,1995)$ test the HeckscherOhlin-Vanek theorem using data on factor endowments, trade flows on the industry level and the U.S. input-output table. In this simplified version, we will use the level of financial development, trade flows on the industry level and dependence on external finance to test the Kletzer and Bardhan model. Specifically, we will calculate the weighted average external dependence of a country's exports and trade balance and explore correlations between these measures and indicators of financial sector development. A positive correlation can be considered evidence in favor of the Kletzer and Bardhan model, since it would indicate that countries with higher levels of financial development are net exporters of goods that are produced by industries that rely more on external finance. Thus, we do not reassess the Heckscher-OhlinVanek theorem. Rather, we use the logic behind this theorem for this alternative test of the Kletzer and Bardhan model. Unlike the regression analysis described above, this test does not control for other industry-specific and country-specific determinants of exports and the trade balance.

\section{The Data}

Our sample contains 56 countries and 36 industries. This section describes the measure of external dependence, the indicators of financial development and the trade data. Table 1 presents descriptive statistics and correlation.

\footnotetext{
${ }^{9}$ See LLSV $(1997,1998)$ and Levine (1999).
} 


\subsection{External Dependence}

The industry-level data on external dependence are from a study by Rajan and Zingales (1998). The underlying assumption for their and for our work is that for technological reasons some industries rely more on external finance than others. Scale economies, gestation period or intermediate product intensity might constitute some of these technological reasons. However, in general equilibrium the amount of external finance in an economy is the result of both production and funding decisions of producers and consumption-savings decisions of consumers, so both demand and supply. In countries with perfect and atomistic capital markets, however, Rajan and Zingales note that individual large firms that constitute a fraction of the overall market and therefore have no market power might face a perfectly elastic supply curve, so that the actual use of external finance by these firms would primarily reflect the demand for it. ${ }^{10}$ Assuming that the variance of the reliance on external finance across industries persists across countries we can thus use the actual external dependence of industries as observed for large firms in a country with a relatively well developed financial system as proxying for the "natural" dependence of industries on external finance in other countries. Following Rajan and Zingales, we use a sample of publicly listed firms in the U.S. to compute the natural external dependence of industries, and then confirm our results using a sample of Canadian firms to compute the external dependence of industries.

Rajan and Zingales use data from Standard and Poor's Compustat for U.S. firms in 36 industries. A firm's dependence on external finance is defined as the share of investment that cannot be financed through internal cash flows; or as capital expenditures minus cash flow from operations divided by capital expenditures. Both numerator and denominator are averaged over the 1980s to smooth temporal fluctuations. The industry values are calculated

\footnotetext{
${ }^{10}$ Even if capital markets are not perfect, but the elasticity of supply does not change substantially across industries, the actual amount of external finance used is still a reasonable measure of relative demand. See Rajan and Zingales (1998).
} 
as medians rather than means to thus prevent outliers from dominating the results. We have data for 36 industries varying from Tobacco, an industry with no demand, to Drugs, the industry with the highest use of external finance.

\subsection{Indicators of Financial Development}

Our primary measure of financial intermediary development is PRIVATE CREDIT, which equals the value of credits by financial intermediaries to the private sector divided by GDP. It captures the amount of credit channeled through financial intermediaries to private firms. Recent research has shown a robust link between PRIVATE CREDIT and economic growth (Levine, Loayza, and Beck 2000). In our sensitivity analysis we include two further measures of financial intermediary development. LIQUID LABILITIES equals the liquid liabilities of the financial system (currency plus demand and interest-bearing liabilities of banks and nonbank financial intermediaries) divided by GDP. COMMERCIAL-CENTRAL BANK equals the ratio of commercial banks' domestic assets divided by commercial banks' and central bank's domestic assets. ${ }^{11}$

Our primary measure of stock market development is MARKET CAPITALIZATION, which equals the value of listed domestic shares on domestic exchanges divided by GDP. This is an indicator of the size of the secondary stock market. Unlike PRIVATE CREDIT, however, MARKET CAPITALIZATION does not measure the amount of funding available to firms, but rather the discounted value of future earnings. It might therefore overestimate the importance of the stock market in obtaining external funds. ${ }^{12}$ Furthermore, MARKET CAPITALIZATION indicates the size rather than the activity of stock markets. In the sensitivity analysis we therefore use two measures of stock market liquidity. VALUE TRADED equals the value of the trades of domestic shares on domestic exchanges divided by GDP.

\footnotetext{
${ }^{11}$ Both measures have been used by other researchers, see King and Levine (1993 a,b)

${ }^{12}$ See Rajan and Zingales (1998).
} 
TURNOVER equals the value of the trades of domestic shares on domestic exchanges divided by the value of listed domestic shares. ${ }^{13}$

Finally, we use two measures of the overall importance of the financial sector. TOTAL CAPITALIZATION is the sum of MARKET CAPITALIZATION and PRIVATE CREDIT. It captures the overall size of the financial sector by including all financial institutions and the equity market and by combining our primary measures of financial intermediary and stock market development. In the sensitivity analysis we use ACCOUNTING, a measure of the comprehensiveness of companies' balance sheets and income statements. The higher ACCOUNTING, the easier it should be for firms to obtain external finance, either from financial intermediaries or financial markets.

There is a significant variation in financial development across the countries included in our sample. Whereas PRIVATE CREDIT is only $2 \%$ in Ghana, it is $160 \%$ in Switzerland. Similarly, MARKET CAPITALIZATION is only $0.5 \%$ in Uruguay, but $67 \%$ in Japan.

\subsection{The Trade Data}

Data on exports and imports for the 36 industries are from the United Nations Statistical Office COMTRADE database. Exports are reported at f.o.b. (free on board) values and imports at c.i.f. (cost, insurance, freight) values. The data are in U.S. dollars and averaged over the ten-year period 1980-89. They are deflated by export and import price indices obtained from the World Development Indicators (WDI) of the World Bank. To obtain the share of industry exports and imports in GDP, we divide by real GDP, using WDI data. There is a wide variation in industry export shares and trade balances. While Nigeria's exports in the petroleum refineries industry constitute 39\% of GDP, Bolivia's exports of petroleum and coal products constitute less than $0.01 \%$ of GDP. Nigeria has also the largest industry trade surplus in the sample, again in the petroleum refineries industry, whereas Ghana has the largest industry trade deficit in the sample, in the motor vehicles industry.

\footnotetext{
${ }^{13}$ Both measures were used by Levine and Zervos (1998).
} 


\section{The Basic Results}

The results in Table 2 are evidence in favor of our hypothesis that countries with better developed financial institutions and markets have a comparative advantage in industries that use more external finance. We find significant and positive coefficients on the interaction terms between external dependence and financial development in the export and trade balance equations. This supports the theoretical model by Kletzer and Bardhan (1987) that predicts higher exports and a larger trade balance in externally dependent industries for countries with less capital market restrictions. While we cannot reject the possibility that there is a link from the structure of the trade balance to the development of the financial sector and the use of external finance, using the legal origin to extract the exogenous component of financial development and dropping the U.S. from our sample allows us to conclude that the positive relationship is not only due to reverse causality or simultaneity bias.

We start with TOTAL CAPITALIZATION, our most comprehensive measure of financial sector development. The results indicate that in countries with a higher level of TOTAL CAPITALIZATION, industries using external finance have higher exports and larger trade balances. To illustrate this consider the furniture industry, which has the median value for external dependence (0.24) across the 36 industries. The regression results predict that a $10 \%$ higher level of financial development results in a $3.1 \%$ higher export share of furniture in GDP and a 3.4\% higher trade balance.

The results are also evidence for the importance of financial development for the trade patterns across countries. Consider the industries at the 25th percentile (low external dependence) and 75th percentile (high external dependence), Beverages and Machinery, respectively. A 10\% higher level of TOTAL CAPITALIZATION implies 1\% higher exports and a 1.1\% larger trade balance in Beverages (external dependence=0.08), and $5.7 \%$ higher exports and a $6.4 \%$ larger trade balance in Machinery (external dependence $=0.45$ ). This indicates that the positive relationship between financial development 
and export share and trade balance increases in the external dependence of the industry. This result is consistent with the Kletzer and Bardhan model in that countries with less capital market restrictions and therefore higher levels of financial development have a comparative advantage in industries that use more external financing.

The results in columns 2 and 3 suggest that both financial intermediary and stock market development are important sources of comparative advantage. The coefficients on the interaction terms of both PRIVATE CREDIT and MARKET CAPITALIZATION are significantly positive at the onepercent level. When we include both PRIVATE CREDIT and MARKET CAPITALIZATION in a regression, however, only the interaction term with PRIVATE CREDIT exhibits a significant coefficient (column 4). This suggests that stock market development is not an independent source of comparative advantage or that the exogenous component of MARKET CAPITALIZATION does not contain any additional information about the development of the financial sector that is not contained in PRIVATE CREDIT. ${ }^{14}$

As alternative to the regression analysis we can explore the correlation between the weighted average external dependence of a country's exports and trade balance and our indicators of financial sector development. ${ }^{15}$ This

\footnotetext{
${ }^{14}$ Since these results might be due to the fact that PRIVATE CREDIT and MARKET CAPITALIZATION "share" the legal origin dummies as instrumental variables, we also include interaction terms of external dependence with the share of Catholic, Muslim and Protestant population as instrumental variables. Anecdotal and statistical evidence suggests that the development of institutions is partly driven by the dominant religion in a country. See LLSV (1999). However, since the legal origin and religious composition are correlated, even this extended instrumental variable set might not contain enough information to extract the exogenous component of financial intermediary and the distinct exogenous component of stock market development.

${ }^{15}$ We calculate the weighted average external dependence of a country's exports by multiplying each industry's external dependence with its share in total manufacturing exports of the country. To get the weighted average external dependence of a country's trade balance, we take the difference between the country's weighted average external dependence of exports and imports.
} 
amounts to a test whether countries with better developed financial systems export goods produced by industries that use more external finance.

Table 3 ranks the countries in our sample according to the weighted average external dependence of their exports and their trade balance. ${ }^{16}$ We note that two of the world's financially most developed countries - Japan and Switzerland - also have the highest weighted average external dependence of exports and trade balance. There are certainly surprises - Chile has a relatively low weighted average external dependence of exports and trade balance, while Paraguay has a relatively high weighted average external dependence of the trade balance, although their respective levels of financial development would predict otherwise. However, this ranking does not control for other country- and industry-specific effects, unlike the regression analysis performed in the rest of the paper. Unlike the factor content studies of the Heckscher-Ohlin-Vanek theorem this ranking does also not take into account other production factors and country endowments. It thus constitutes only a partial analysis.

The correlations reported in Table 4 support our hypothesis and the Kletzer and Bardhan model. The weighted average external dependence of the exports and the trade balance is significantly and positively correlated with all three measures of financial development. This confirms the previous regression results that the exports and the trade balance of financially more developed countries tend to be dominated by goods that are produced by industries using more external financing.

\section{Robustness Tests}

\subsection{Simultaneity Bias and Reverse Causality}

Are the results reported so far due to simultaneity bias or reverse causality? Although the results obtained from the TSLS regressions control for simul-

\footnotetext{
${ }^{16}$ As before, the U.S. is not included in the sample.
} 
taneity bias and possible reverse causality, there are more direct ways to test for this. Following Rajan and Zingales (1998), we split the sample into two subsamples, export shares and trade balances above and below the median for a country.

The results in the top panel of Table 5 indicate that our previous results are not due to a spurious correlation. By restricting the sample to the industries that have export shares and trade balances above the median, we take account of the fact that an economy's endowment, such as natural resources, might give it a comparative advantage in industries that also use a lot of external finance. Although the size of the coefficients is smaller than in Table 2, the coefficients on all interaction terms are still significant at the five-percent level, except for the interaction term of external dependence with MARKET CAPITALIZATION in the trade balance regression. As in Table 2, the interaction term with MARKET CAPITALIZATION enters insignificantly once we control for the interaction of external dependence with PRIVATE CREDIT.

The results in the bottom panel of Table 5 provide somewhat weaker evidence that our previous results are not due to reverse causality. By restricting our sample to industries with export shares and trade balances below the median, we take account of the concern that financial institutions and markets might have arisen due to a demand from industries that are dependent on external finance and that constitute a large part of a country's exports. The results are less assuring, although most coefficients on the interaction terms still enter significantly positive at the 10-percent level. Exceptions are the regressions where we include the interaction of external dependence with both PRIVATE CREDIT and MARKET CAPITALIZATION. ${ }^{17}$

\footnotetext{
${ }^{17}$ We also split the sample according to the industry's share in total manufacturing production, rather than exports or trade balance, a test proposed by Rajan and Zingales. We find that the interaction of external dependence and financial development is insignificant for industries above the median and significant for industries below the median. Results available on request. While this seems to shed doubt on our previous results, two qualifications have to be made. First, the number of countries decreases to 36 for these regressions,
} 


\subsection{Alternative Measures of External Dependence}

The Rajan and Zingales (1998) data set provides us with three alternative measures of external dependence that allow us to test the sensitivity of our results to the measure of external dependence that we have used so far. The three alternative measures of external dependence are significantly correlated with our principal measure of external dependence at the one-percent level, with correlation coefficients being at least $60 \% .^{18}$

The results in Table 6 show that the results are robust to using a measure of external dependence calculated for U.S. firms that went public during the previous ten years. Rajan and Zingales show that the use of external finance is highest during the early years of a company. Using a sample of young firms to calculate the dependence on external finance might therefore give a more appropriate picture of the reliance on external finance. ${ }^{19}$ The coefficients on most interaction terms are significantly positive. The smaller size of the coefficients reflects the higher use of external finance by young firms. Whereas furniture - the median industry for both samples - has an external dependence ratio of 0.24 in the sample for all firms, it has an external dependence of 0.68 in the young firms' sample. Using the results from Table 7, a $10 \%$ increase in TOTAL CAPITALIZATION therefore increases the export share of the median industry by $3.4 \%$, a stronger effect than when using the results from the sample with all firms. ${ }^{20}$ Interestingly, when including interaction terms with both PRIVATE CREDIT and MARKET CAPITALIZATION, only the latter enters significantly positive in the export regressions, while only the former enters significantly in the trade balance regression. This seems to shed doubt on the previous results, that it is financial intermediaries rather than

since Rajan and Zingales' sample is smaller. Second, the industrial structure of a country is not necessarily determined by the same factors as the structure of its exports.

${ }^{18}$ Data available on request.

${ }^{19}$ The average external dependence is more than twice as high for the sample of young firms (0.68) than for the sample of all firms (0.32).

${ }^{20}$ As reported above a $10 \%$ increase in TOTAL CAPITALIZATION increases the export share of the median industry - furniture - by $3.1 \%$, when using the sample for all industries. 
financial markets that provide the necessary external financing for export industries.

Table 7 shows that the results are robust to using a measure of external dependence that is calculated for a sample of listed U.S. firms over the period 1970-79. Rajan and Zingales propose that if countries other than the U.S. use older technologies, the external dependence as measured over the $80 \mathrm{~s}$ might not reflect well the reliance on external finance in other countries, especially developing countries. ${ }^{21}$ We therefore rerun the regressions using the external dependence measured over the 70s. The coefficients on all interaction terms are significantly positive and the coefficient size increases. When including interaction terms with both PRIVATE CREDIT and MARKET CAPITALIZATION, they are jointly significant, while the interaction term with MARKET CAPITALIZATION is insignificant and the interaction term with PRIVATE CREDIT is significant only at the 10 percent-level.

Finally, the results in Table 8 indicate that our previous results are not due to peculiar characteristics of industries in the U.S. We use the external dependence as calculated for a sample of Canadian firms. Although Canada has a different financial structure, its financial system can be considered as well developed as the financial system of the U.S. Using data from Canadian firms should therefore not alter our results. ${ }^{22}$ The results in Table 8 show that the coefficients on most interaction terms are significantly positive at the five-percent level. When including interaction terms with both PRIVATE CREDIT and MARKET CAPITALIZATION, however, they are jointly significant only at the 10-percent level.

\footnotetext{
${ }^{21}$ The average external dependence over the $70 \mathrm{~s}$ was 0.08 as compared to 0.32 in the 80 s.

${ }^{22}$ According to Rajan and Zingales, Canada is the only other country for which firmlevel data on flow of funds are available. Our data indicate that the firms in the Canadian sample did not use significantly more or less external resources to finance their capital expenditures than U.S. firms.
} 


\subsection{Further Robustness Tests}

Our results are robust to the use of other indicators of financial development, proposed in the literature. The interaction tems of external dependence with all five additional indicators of financial development described in section 4 enter significantly positive. ${ }^{23}$

Financial development does not proxy for other possible determinants of comparative advantage. To control for other potential determinants of comparative advantage, we interact external dependence with a measure of schooling (log of one plus the average years of schooling in the population over the age of 25 in 1980) and with the log of real per capita GDP in 1980 in the regressions. ${ }^{24}$ Industries that rely highly on external finance, might also depend on human capital as an input. Financial development might also proxy for the general level of development, as measured by per capita income. Although the coefficient on the interaction term with GDP per capita is significant in some regressions, it is not robustly positive in all regressions. The coefficient on the interaction term with schooling does not enter significantly in any of the regressions. Including these additional interaction terms does not change significance or size of the coefficients on the interaction term of financial development and external finance. ${ }^{25}$

Our results are robust to the use of alternative instruments for financial development. We replace legal origin and religious composition as instruments

\footnotetext{
${ }^{23}$ Results available on request. We also ran regressions including interaction terms with one indicator of financial intermediary development (LIQUID LIABILTIES or COMMERCIAL-CENTRAL BANK) and one stock market indicator (VALUE TRADED or TURNOVER RATIO). While the interaction with LIQUID LIABILITIES does not enter significantly, the interactions with either stock market indicator do. While the interaction with COMMERCIAL-CENTRAL BANK enters significantly positive in the export share regression and neither of the interaction terms with the stock market indicator does, it is the other way around in the trade balance regressions. This sheds additional doubts on whether financial intermediary or stock market development is the dominating channel.

${ }^{24}$ Schooling data are from Barro and Lee (1996), GDP data from Loayza, Lopez, Schmidt-Hebbel, and Serven (1998).

${ }^{25}$ Results available on request.
} 
by measures of the legal rights of secured creditors and minority shareholder, and indicators of institutional quality. Using these alternative instruments does not change our results. ${ }^{26}$

\section{Concluding Remarks}

This paper examined whether countries with better developed financial systems enjoy a comparative advantage in industries that use more external finance. We use a methodological approach developed by Rajan and Zingales (1998) by regressing export and trade shares on the interaction between external dependence across industries and financial development across countries.

Our results provide robust evidence for our hypothesis. Using different measures of financial development and external dependence, our results indicate that, everything else equal, countries with a higher level of financial development have higher export shares and trade balances in industries that rely more on external finance. We control for the possibility that our results are driven by reverse causality or simultaneity bias by using the legal origin of countries as instrumental variables for financial development. By restricting our sample to industries with export shares or trade balances above or below the median for a country, we provide further evidence against the hypotheses that our results might be driven by the simultaneous determination of export specialization and financial development or that the development of the financial sector simply follows the real sector. While the results suggest that both financial institutions and markets are important in channeling external funds to firms and thus determining international trade flows, we cannot determine whether they function through independent channels.

We also show that there are positive correlations between the weighted average external dependence of a country's exports and trade balance and its level of financial development. This simple variation of the factor-content studies by Bowen, Leamer, and Sveikauskas (1987) and Trefler (1993, 1995)

\footnotetext{
${ }^{26}$ Results available on request.
} 
indicates that countries with higher levels of financial sector development are net exporters of goods that are produced by industries with higher reliance on external financing.

The results of this paper provide the first empirical examination of a small literature on the link between international trade and financial development. Specifically, we provide supporting evidence for the models developed by Kletzer and Bardhan (1987) that show that countries with less capital market restrictions have a comparative advantage in industries with higher external financing needs.

Our results have implications for policy reforms in both the financial and the trade sector. Suppose a country with a low level of financial development undertakes financial sector reforms that raise the level of external finance available to private enterprises. These reforms might include strengthening creditor rights and contract enforcement through judiciary and judicial reforms. ${ }^{27} \mathrm{~A}$ subsequent increase in external finance available to private enterprises implies a shift in comparative advantage, away from industries that do not rely on external finance towards industries that rely relatively more on external finance. While exporters in industries with no use of external finance might see their export shares decrease, relative to other industries, and face more competition from other financially less developed countries, exporters in industries that rely more on external finance might gain export shares.

Suppose a country embarks on trade reforms, lowering import tariffs across the board and thus exposing domestic industries of exportable goods to international competition. ${ }^{28}$ If the country has a high level of financial development, this new competition might affect industries that rely less on external finance more than other industries. If, on the other hand, the country has a low level of financial development, industries that rely relatively more on external finance, might be hurt most.

\footnotetext{
${ }^{27}$ For the importance of creditor rights and contract enforcement see LLSV (1997) and Levine, Loayza and Beck (2000).

${ }^{28}$ Trade policy certainly includes other instruments, such as non-tariff barriers, export monopolies and exchange rate policy. See, among others, Sachs and Warner (1995).
} 


\section{References}

Baldwin, Richard E.(1989): Exporting the Capital Markets: Comparative Advantage and Capital Market Imperfections, in: Audretsch, David B.,

Sleuwaegen, Leo, and Yamawaki, Hideki (Eds.): The Convergence of International and Domestic Markets, North-Holland, Amsterdam, 135152.

Barro, Robert J. and Lee, Jong-Wha(1996): International Measures of Schooling Years and Schooling Quality, American Economic Review 86, 21823.

Bowen, Harry P., Leamer, Edward E., and Sveikauskas, Leo (1987): Multicountry, Multifactor Tests of the Factor Abundance Theory, American Economic Review 7r, 791-809.

Jones, Ronald W. (1984): The Positive Theory of International Trade, in: Jones, Ronald W. and Kenen, Peter B. (Eds.): Handbook of International Economics, vol. 1, Elsevier Science Publishers B.V., Amsterdam, $1-62$.

King, Robert G. und Levine, Ross (1993a): Finance and Growth: Schumpeter Might Be Right, Quarterly Journal of Economics 108, 717-737.

King, Robert G. und Levine, Ross (1993b): Finance, Entrepreneurship, and Growth. Theory and Evidence, Journal of Monetary Economics 32, $513-42$.

Kletzer, Kenneth and Bardhan, Pranab (1987): Credit Markets and Patterns of International Trade, Journal of Development Economics 2\%, 57-70.

La Porta, Rafael, Lopez-de-Silanes, Florencio, Shleifer, Andrei, and Vishny, Robert W. (1997): Legal Determinants of External Finance, Journal of Finance 52, 1131-1150. 
La Porta, Rafael, Lopez-de-Silanes, Florencio, Shleifer, Andrei, and Vishny, Robert W. (1998): Law and Finance, Journal of Political Journal 106, 1113-1155.

La Porta, Rafael, Lopez-de-Silanes, Florencio, Shleifer, Andrei, and Vishny, Robert W. (1999): The Quality of Government, Journal of Law, Economics, and Organization 15, 222-279.

Levine, Ross (1997): Financial Development and Economic Growth. Views and Agenda, Journal of Economic Literature 35, 688-726.

Levine, Ross (1998): The Legal Environment, Banks, and Long-Run Economic Growth, Journal of Money, Credit, and Banking 30, 596-620.

Levine, Ross, Loayza, Norman, and Beck, Thorsten (1999): Financial Intermediation and Economic Growth: Causality and Causes, Journal of Monetary Economics 46, 31-77.

Levine, Ross and Zervos, Sara (1998): Stock Markets, Banks, and Economic Growth, American Economic Review, 88, 537-58.

Loayza, Norman, Lopez, Humberto, Schmidt-Hebbel, Klaus, and Serven, Luis (1998): The World Saving Data Base, The World Bank http://www.worldbank.org/research/projects/savings/policies.htm

Rajan, Raghuram G. and Zingales, Luigi (1998): Financial Dependence and Growth, American Economic Review 88, 559-86.

Reynolds, Thomas H. and Flores, Arturo A. (1996): Foreign Law: Current Sources of Codes and Basic Legislation in Jurisdictions of the World, Fred B. Rothman \& Co., Littleton, CO.

Sachs, Jeffrey and Warner, Andrew (1995): Economic Reform and the Process of Global Integration, Brookings Papers on Economic Activity 1995:1, $1-118$. 
Trefler, Daniel (1993): International Factor Price Differences: Leontief Was Right!, Journal of Political Economy 101, 961-987.

Trefler, Daniel (1995): The Case of the Missing Trade and Other Mysteries, American Economic Review 85, 1029-1046. 
Table 1: Summary Statistics

\begin{tabular}{|c|c|c|c|c|c|c|}
\hline & Mean & $\begin{array}{l}\text { Standard } \\
\text { deviation }\end{array}$ & Median & Minimum & Maximum & $\begin{array}{c}\text { Number of } \\
\text { observations }\end{array}$ \\
\hline Export share & 0.39 & 1.44 & 0.06 & 0.00 & 38.89 & 1981 \\
\hline Trade balance & -0.12 & 1.50 & -0.07 & -11.16 & 37.81 & 1981 \\
\hline Private Credit & 45.98 & 34.46 & 35.15 & 2.36 & 160.20 & 57 \\
\hline Liquid Liabilities & 48.23 & 27.69 & 46.19 & 12.58 & 156.84 & 57 \\
\hline Commercial-Central Bank & 76.69 & 18.49 & 80.70 & 23.47 & 99.54 & 57 \\
\hline Market Capitalization & 17.89 & 18.87 & 10.09 & 0.45 & 67.23 & 42 \\
\hline Value Traded & 8.86 & 21.49 & 2.71 & 0.02 & 131.26 & 41 \\
\hline Turnover & 30.28 & 43.83 & 24.75 & 0.17 & 273.95 & 41 \\
\hline Total Capitalization & 71.57 & 51.28 & 59.71 & 14.93 & 218.83 & 42 \\
\hline Accounting & 60.09 & 13.93 & 62 & 24 & 83 & 35 \\
\hline External dependence (U.S., 80s) & 0.32 & 0.41 & 0.24 & -0.45 & 1.49 & 36 \\
\hline External dependence (U.S, young firms) & 0.68 & 0.64 & 0.68 & -1.53 & 2.06 & 34 \\
\hline External dependence (U.S., 70s) & 0.08 & 0.19 & 0.07 & -0.45 & 0.54 & 35 \\
\hline External dependence (Canadian firms) & 0.43 & 0.77 & 0.38 & -0.80 & 3.51 & 27 \\
\hline
\end{tabular}

\section{Correlation Between Measures of Financial Development}

\begin{tabular}{|c|c|c|c|c|c|c|c|c|}
\hline & $\begin{array}{l}\text { Private } \\
\text { Credit }\end{array}$ & $\begin{array}{l}\text { Liquid } \\
\text { Liabilities }\end{array}$ & $\begin{array}{l}\text { Commercial- } \\
\text { Central Bank } \\
\end{array}$ & $\begin{array}{l}\text { Market } \\
\text { Capitalization }\end{array}$ & $\begin{array}{l}\text { Value } \\
\text { Traded }\end{array}$ & Turnover & $\begin{array}{l}\text { Total } \\
\text { Capitalization }\end{array}$ & Accounting \\
\hline Private Credit & 1 & & & & & & & \\
\hline Liquid Liabilities & $\begin{array}{c}0.82 \\
(0.001)\end{array}$ & 1 & & & & & & \\
\hline Commercial-Central Bank & $\begin{array}{c}0.68 \\
(0.001)\end{array}$ & $\begin{array}{c}0.51 \\
(0.001)\end{array}$ & 1 & & & & & \\
\hline Market Capitalization & $\begin{array}{c}0.71 \\
(0.001)\end{array}$ & $\begin{array}{c}0.62 \\
(0.001)\end{array}$ & $\begin{array}{c}0.54 \\
(0.001)\end{array}$ & 1 & & & & \\
\hline Value Traded & $\begin{array}{c}0.69 \\
(0.001)\end{array}$ & $\begin{array}{c}0.64 \\
(0.001)\end{array}$ & $\begin{array}{c}0.36 \\
(0.022)\end{array}$ & $\begin{array}{c}0.64 \\
(0.001)\end{array}$ & 1 & & & \\
\hline Turnover & $\begin{array}{c}0.58 \\
(0.001)\end{array}$ & $\begin{array}{c}0.48 \\
(0.002)\end{array}$ & $\begin{array}{c}0.30 \\
(0.059)\end{array}$ & $\begin{array}{c}0.44 \\
(0.004)\end{array}$ & $\begin{array}{c}0.92 \\
(0.001)\end{array}$ & 1 & & \\
\hline Total Capitalization & $\begin{array}{c}0.97 \\
(0.001)\end{array}$ & $\begin{array}{c}0.81 \\
(0.001)\end{array}$ & $\begin{array}{c}0.67 \\
(0.001)\end{array}$ & $\begin{array}{c}0.87 \\
(0.001)\end{array}$ & $\begin{array}{c}0.72 \\
(0.001)\end{array}$ & $\begin{array}{c}0.57 \\
(0.001)\end{array}$ & 1 & \\
\hline Accounting & $\begin{array}{c}0.45 \\
(0.007)\end{array}$ & $\begin{array}{c}0.19 \\
(0.273)\end{array}$ & $\begin{array}{c}0.59 \\
(0.001)\end{array}$ & $\begin{array}{c}0.62 \\
(0.001)\end{array}$ & $\begin{array}{c}0.27 \\
(0.120)\end{array}$ & $\begin{array}{c}0.24 \\
(0.161)\end{array}$ & $\begin{array}{c}0.55 \\
(0.001)\end{array}$ & 1 \\
\hline
\end{tabular}

Export share $=$ share of an industry's exports in GDP

Trade balance $=$ ratio of an industry's trade balance to GDP

External dependence (U.S., 80s) = fraction of capital expenditures not financed with internal funds for U.S. firms in the same industry between 1980-1990. Source: Rajan and Zingales (1998)

External dependence (U.S, young firms) = fraction of capital expenditures not financed with internal funds for U.S. firms that went public during the previous 10 years in the same industry

between 1980-1990. Source: Rajan and Zingales (1998)

External dependence (U.S., 70s) = fraction of capital expenditures not financed with internal funds for U.S. firms in the same industry between 1970-80. Source: Rajan and Zingales (1998)

External dependence (Canadian firms) = fraction of capital expenditures not financed with internal funds for Canadian firms in the same industry between 1980-1990. Source: Rajan and Zingales (1998)

PRIVATE CREDIT = credit by deposit money banks and other financial institutions to the private sector divided by GDP, times 100 .

LIQUID LIABILITIES = liquid liabilities of the financial system (currency plus demand and interest-bearing liabilities of banks and nonbank financial intermediaries) divided by GDP, times 100 .

COMMERCIAL-CENTRAL BANK = assets of deposit money banks divided by assets of deposit money banks plus central bank assets, times 100 .

MARKET CAPITALIZATION = value of listed domestic shares on domestic exchanges divided by GDP, times 100

VALUE TRADED = value of the trades of domestic shares on domestic exchanges divided by GDP times 100

TURNOVER = value of the trades of domestic shares on domestic exchanges divided by the value of listed domestic shares on domestic exchanges, times 100

TOTAL CAPITALIZATION = PRIVATE CREDIT + MARKET CAPITALIZATION

ACCOUNTING = index of the comprehensiveness and quality of company reports 


\section{Table 2: Industry Exports and Trade Balances and Financial Development}

\begin{tabular}{|c|c|c|c|c|}
\hline Dependent variable & Export share & Export share & Export share & Export share \\
\hline $\begin{array}{l}\text { Interaction (external dependence } \\
\mathrm{x} \text { log[TOTAL CAPITALIZATION] ) }\end{array}$ & $\begin{array}{c}1.274 \\
(0.001)\end{array}$ & & & \\
\hline $\begin{array}{l}\text { Interaction (external dependence } \\
\text { x log[PRIVATE CREDIT] ) }\end{array}$ & & $\begin{array}{c}1.259 \\
(0.001)\end{array}$ & & $\begin{array}{l}1.256 \\
(0.005)\end{array}$ \\
\hline $\begin{array}{l}\text { Interaction (external dependence } \\
\mathrm{x} \text { log[MARKET CAPITALIZATION] ) }\end{array}$ & & & $\begin{array}{c}0.766 \\
(0.001)\end{array}$ & $\begin{array}{c}0.079 \\
(0.768)\end{array}$ \\
\hline F-test joint significance & & & & $\begin{array}{c}17.28 \\
(0.001)\end{array}$ \\
\hline Number of observations & 1420 & 1945 & 1420 & 1420 \\
\hline Dependent variable & Trade balance & Trade balance & Trade balance & Trade balance \\
\hline $\begin{array}{l}\text { Interaction (external dependence } \\
\mathrm{x} \text { log[TOTAL CAPITALZATION] ) }\end{array}$ & $\begin{array}{c}1.430 \\
(0.001)\end{array}$ & & & \\
\hline $\begin{array}{l}\text { Interaction (external dependence } \\
\mathrm{x} \text { log[PRIVATE CREDIT] ) }\end{array}$ & & $\begin{array}{c}1.421 \\
(0.001)\end{array}$ & & $\begin{array}{l}1.736 \\
(0.001)\end{array}$ \\
\hline $\begin{array}{l}\text { Interaction (external dependence } \\
\mathrm{x} \text { log[MARKET CAPITALIZATION] ) }\end{array}$ & & & $\begin{array}{c}0.810 \\
(0.001)\end{array}$ & $\begin{array}{l}-0.080 \\
(0.789)\end{array}$ \\
\hline F-test joint significance & & & & $\begin{array}{c}18.00 \\
(0.001)\end{array}$ \\
\hline Number of observations & 1420 & 1945 & 1420 & 1420 \\
\hline
\end{tabular}

All regressions include country and industry dummies

$\mathrm{P}$-values from heteroskedasticty robust standard errors are reported in parentheses

All regressions are estimated using the English, French and German legal origin dummies as instrumental variables for the financial development indicators. In column 4 the shares of Catholic, Muslim and Protestant population in total population are included as additional instrumental variables. The F-test is for the joint significance of both interaction terms of external dependence with PRIVATE CREDIT and MARKET CAPITALIZATION.

Export share $=$ share of an industry's exports in GDP

Trade balance $=$ ratio of an industry's trade balance to GDP

External dependence $=$ share of capital expenditures not financed with internal funds for U.S. firms in the same industry between $1980-90$.

Source: Rajan and Zingales (1998)

PRIVATE CREDIT = credit by deposit money banks and other financial institutions to the private sector divided by GDP, times 100 .

MARKET CAPITALIZATION = value of listed domestic shares on domestic exchanges divided by GDP, times 100.

TOTAL CAPITALIZATION = PRIVATE CREDIT + MARKET CAPITALIZATION 
Table 3: Ranking of Countries According to Weighted Average Exterrnal Dependence of Exports and Trade Balance

\begin{tabular}{|c|c|c|c|}
\hline Country name & $\begin{array}{l}\text { Weighted Average External } \\
\text { Dependence of Exports }\end{array}$ & Country name & $\begin{array}{l}\text { Weighted Average External } \\
\text { Dependence of Trade Balance }\end{array}$ \\
\hline Japan & 0.52 & Japan & 0.21 \\
\hline Switzerland & 0.52 & Switzerland & 0.15 \\
\hline Ireland & 0.49 & Ireland & 0.07 \\
\hline Israel & 0.43 & Paraguay & 0.04 \\
\hline Malaysia & 0.40 & Denamrk & 0.03 \\
\hline Great Britain & 0.39 & Israel & 0.01 \\
\hline Sweden & 0.37 & Great Britain & 0.00 \\
\hline Denmark & 0.37 & France & 0.00 \\
\hline France & 0.35 & Sweden & -0.01 \\
\hline Korea & 0.35 & Lauritius & -0.01 \\
\hline Austria & 0.35 & Italy & -0.01 \\
\hline Italy & 0.32 & Belgium & -0.02 \\
\hline Canada & 0.30 & Bolivia & -0.03 \\
\hline Netherlands & 0.30 & Jamaica & -0.03 \\
\hline Belgium & 0.30 & Austria & -0.04 \\
\hline Finland & 0.28 & Netherlands & -0.06 \\
\hline Spain & 0.28 & Korea & -0.06 \\
\hline Costa Rica & 0.28 & Guatemala & -0.07 \\
\hline Guatemala & 0.28 & Malaysia & -0.07 \\
\hline Philippines & 0.28 & Nigeria & -0.07 \\
\hline Thailand & 0.26 & Philippines & -0.08 \\
\hline Portugal & 0.25 & Costa Rica & -0.09 \\
\hline Mexico & 0.24 & Finland & -0.10 \\
\hline India & 0.23 & India & -0.10 \\
\hline Brazil & 0.22 & Togo & -0.11 \\
\hline Norway & 0.21 & Portugal & -0.11 \\
\hline El Salvador & 0.21 & Thailand & -0.12 \\
\hline Jamaica & 0.21 & Ghana & -0.13 \\
\hline Australia & 0.17 & Canada & -0.13 \\
\hline Morocco & 0.16 & Spain & -0.13 \\
\hline Argentina & 0.16 & Bangaldesh & -0.14 \\
\hline Mauritius & 0.16 & Senegal & -0.15 \\
\hline Honduras & 0.16 & Morocco & -0.15 \\
\hline Senegal & 0.16 & Norway & -0.16 \\
\hline Paraguay & 0.16 & Mexico & -0.18 \\
\hline Dominican Republic & 0.16 & Greece & -0.19 \\
\hline New Zealand & 0.15 & El Salvador & -0.19 \\
\hline Colombia & 0.15 & Brazil & -0.19 \\
\hline Togo & 0.14 & Dominican Republic & -0.19 \\
\hline Greece & 0.13 & Madagascar & -0.20 \\
\hline Kenya & 0.13 & Colombia & -0.21 \\
\hline Madagascar & 0.13 & Honduras & -0.23 \\
\hline Bangladesh & 0.11 & New Zealand & -0.24 \\
\hline Trinidad and Tobago & 0.09 & Pakistan & -0.24 \\
\hline Pakistan & 0.09 & Syria & -0.24 \\
\hline Bolivia & 0.09 & Kenya & -0.25 \\
\hline Ecuador & 0.09 & Australia & -0.25 \\
\hline Peru & 0.08 & Trinidad and Tobago & -0.27 \\
\hline Uruguay & 0.08 & Argentina & -0.28 \\
\hline Syria & 0.08 & Egypt & -0.29 \\
\hline Chile & 0.07 & Peru & -0.29 \\
\hline Ghana & 0.05 & Algeria & -0.31 \\
\hline Venezuela & 0.05 & Uruguay & -0.31 \\
\hline Algeria & 0.05 & Chile & -0.32 \\
\hline Nigeria & 0.04 & Ecuador & -0.32 \\
\hline Egypt & 0.04 & Venezuela & -0.34 \\
\hline
\end{tabular}

External dependence $=$ share of capital expenditures not financed with internal funds for U.S. firms in the same industry between $1980-90$ We calculate the weighted average external dependence of a country's exports by multiplying each industry's external dependence with its share in total manufacturing exports of the country. To get the weighted average external dependence of a country's trade balance, we take the difference between the country's weighted average external dependence of exports and imports. 


\section{Table 4: Correlations between Weighted Average Exterrnal Dependence of Exports and Trade Balance and Financial Development}

\begin{tabular}{lcc} 
& \multicolumn{2}{c}{ Weighted Average External Dependence of } \\
& Exports & Trade Balance \\
\hline TOTAL CAPITALIZATION & 0.715 & 0.612 \\
& $(0.001)$ & $(0.001)$ \\
& 41 & 41 \\
PRIVATE CREDIT & 0.669 & 0.473 \\
& $(0.001)$ & $(0.001)$ \\
& 56 & 56 \\
MARKET CAPITALIZATION & 0.656 & 0.541 \\
& $(0.001)$ & $(0.001)$ \\
& 41 & 41
\end{tabular}

P-values are reported in parentheses and number of countries in the third line

External dependence $=$ share of capital expenditures not financed with internal funds for U.S. firms in the same industry between 1980-90.

We calculate the weighted average external dependence of a country's exports by multiplying each industry's external dependence with its share in total manufacturing exports of the country. To get the weighted average external dependence of a country's trade balance, we take the difference between the country's weighted average external dependence of exports and imports.

PRIVATE CREDIT = credit by deposit money banks and other financial institutions to the private sector divided by GDP, times 100 . MARKET CAPITALIZATION = value of listed domestic shares on domestic exchanges divided by GDP, times 100.

TOTAL CAPITALIZATION = PRIVATE CREDIT + MARKET CAPITALIZATION 


\section{Table 5: Industry Exports and Trade Balances and Financial Development}

Robustness Tests

\section{Above median}

\begin{tabular}{|c|c|c|c|c|c|c|c|c|}
\hline Dependent variable & Export share & Export share & Export share & Export share & Trade balance & Trade balance & Trade balance & Trade balanc \\
\hline $\begin{array}{l}\text { Interaction (external dependence } \\
\mathrm{x} \text { log[TOTAL CAPITALIZATION] ) }\end{array}$ & $\begin{array}{l}0.777 \\
(0.001)\end{array}$ & & & & $\begin{array}{c}0.512 \\
(0.044)\end{array}$ & & & \\
\hline $\begin{array}{l}\text { Interaction (external dependence } \\
\mathrm{x} \text { log[PRIVATE CREDIT] ) }\end{array}$ & & $\begin{array}{l}0.784 \\
(0.001)\end{array}$ & & $\begin{array}{l}1.417 \\
(0.001)\end{array}$ & & $\begin{array}{c}0.530 \\
(0.014)\end{array}$ & & $\begin{array}{c}1.056 \\
(0.030)\end{array}$ \\
\hline $\begin{array}{l}\text { Interaction (external dependence } \\
\mathrm{x} \text { log[MARKET CAPITALIZATION] ) }\end{array}$ & & & $\begin{array}{c}0.359 \\
(0.018)\end{array}$ & $\begin{array}{l}-0.401 \\
(0.114)\end{array}$ & & & $\begin{array}{l}0.144 \\
(0.454)\end{array}$ & $\begin{array}{l}-0.212 \\
(0.520)\end{array}$ \\
\hline F-test joint significance & & & & $\begin{array}{c}8.26 \\
(0.001)\end{array}$ & & & & $\begin{array}{c}4.24 \\
(0.015)\end{array}$ \\
\hline Number of observations & 709 & 969 & 709 & 709 & 709 & 969 & 709 & 709 \\
\hline
\end{tabular}

\section{Below median}

Export share Export share Export share Export share Trade balance Trade balance Trade balance Trade balance

\begin{abstract}
Interaction (external dependence $x \log$ [TOTAL CAPITALIZATION] )

Interaction (external dependence $x \log$ [PRIVATE CREDIT] )

Interaction (external dependence $x \log [$ MARKET CAPITALIZATION]

F-test joint significance
\end{abstract}

Number of observations

\subsection{9}

(0.076)

$\begin{array}{ccc}0.534 & & \\ (0.028) & & 0.202 \\ & & (0.616) \\ & & \\ & 0.346 & 0.118 \\ & (0.083) & (0.636) \\ & & 1.29 \\ & & (0.277) \\ 970 & & 709\end{array}$

970
709
0.506

(0.022)

0.349

(0.054)

0.177

(0.570)

0.419

0.054

(0.800)

0.79

(0.455)

709

The top panel reports the regressions results using export shares and trade balances that are above the respective country median. The bottom panel reports the regressions results using export shares and trade balances that are below the respective country median.

All regressions include country and industry dummies

P-values from heteroskedasticty robust standard errors are reported in parentheses

All regressions are estimated using the English, French and German legal origin dummies as instrumental variables for the financial development indicators. In columns 4 and 8 the shares of Catholic, Muslim and Protestant population in total population are included as additional instrumental variables. The F-test is for the joint significance of both interaction terms of external dependence with PRIVATE CREDIT and MARKET CAPITALIZATION.

Export share $=$ share of an industry's exports in GDP

Trade balance $=$ ratio of an industry's trade balance to GDP

External dependence = share of capital expenditures not financed with internal funds for U.S. firms in the same industry between 1980-90. Source: Rajan and Zingales (1998). PRIVATE CREDIT = credit by deposit money banks and other financial institutions to the private sector divided by GDP, times 100 .

MARKET CAPITALIZATION = value of listed domestic shares on domestic exchanges divided by GDP, times 100.

TOTAL CAPITALIZATION = PRIVATE CREDIT + MARKET CAPITALIZATION 


\section{Table 6: Industry Exports and Trade Balances and Financial Development External Dependence measured using young firms}

\begin{tabular}{|c|c|c|c|c|c|c|c|c|}
\hline Dependent variable & Export share & Export share & Export share & Export share & Trade balance & Trade balance & Trade balance & Trade balance \\
\hline $\begin{array}{l}\text { Interaction (external dependence } \\
\mathrm{x} \text { log[TOTAL CAPITALIZATION] ) }\end{array}$ & $\begin{array}{c}0.502 \\
(0.001)\end{array}$ & & & & $\begin{array}{c}0.646 \\
(0.001)\end{array}$ & & & \\
\hline $\begin{array}{l}\text { Interaction (external dependence } \\
\text { x log[PRIVATE CREDIT] ) }\end{array}$ & & $\begin{array}{c}0.431 \\
(0.001)\end{array}$ & & $\begin{array}{c}0.214 \\
(0.386)\end{array}$ & & $\begin{array}{c}0.639 \\
(0.001)\end{array}$ & & $\begin{array}{c}0.623 \\
(0.024)\end{array}$ \\
\hline $\begin{array}{l}\text { Interaction (external dependence } \\
x \text { log[MARKET CAPITALIZATION] ) }\end{array}$ & & & $\begin{array}{c}0.337 \\
(0.001)\end{array}$ & $\begin{array}{c}0.280 \\
(0.050)\end{array}$ & & & $\begin{array}{c}0.369 \\
(0.001)\end{array}$ & $\begin{array}{c}0.168 \\
(0.269)\end{array}$ \\
\hline F-test joint significance & & & & $\begin{array}{l}12.97 \\
(0.001)\end{array}$ & & & & $\begin{array}{l}13.61 \\
(0.001)\end{array}$ \\
\hline Number of observations & 1341 & 1840 & 1341 & 1341 & 1341 & 1840 & 1341 & 1341 \\
\hline
\end{tabular}

All regressions include country and industry dummies

P-values from heteroskedasticty robust standard errors are reported in parentheses

All regressions are estimated using the English, French and German legal origin dummies as instrumental variables for the financial development indicators. In columns 4 and 8 the shares of Catholic, Muslim and Protestant population in total population are included as additional instrumental variables.

The F-test is for the joint significance of both interaction terms of external dependence with PRIVATE CREDIT and MARKET CAPITALIZATION.

Export share $=$ share of an industry's exports in GDP

Trade balance $=$ ratio of an industry's trade balance to GDP

External dependence = share of capital expenditures not financed with internal funds between 1980-90 for U.S. firms in the same industry which went public in the previous ten years

Source: Rajan and Zingales (1998)

PRIVATE CREDIT = credit by deposit money banks and other financial institutions to the private sector divided by GDP, times 100 .

MARKET CAPITALIZATION = value of listed domestic shares on domestic exchanges divided by GDP, times 100 .

TOTAL CAPITALIZATION = PRIVATE CREDIT + MARKET CAPITALIZATION 


\section{Table 7: Industry Exports and Trade Balances and Financial Development External Dependence measured using firms in the $70 \mathrm{~s}$}

\begin{tabular}{|c|c|c|c|c|c|c|c|c|}
\hline Dependent variable & Export share & Export share & Export share & Export share & Trade balance & Trade balance & Trade balance & Trade balance \\
\hline $\begin{array}{l}\text { Interaction (external dependence } \\
\mathrm{x} \text { log[TOTAL CAPITALIZATION] ) }\end{array}$ & $\begin{array}{l}3.026 \\
(0.001)\end{array}$ & & & & $\begin{array}{c}3.034 \\
(0.001)\end{array}$ & & & \\
\hline $\begin{array}{l}\text { Interaction (external dependence } \\
\text { x log[PRIVATE CREDIT] ) }\end{array}$ & & $\begin{array}{c}2.700 \\
(0.001)\end{array}$ & & $\begin{array}{l}1.717 \\
(0.078)\end{array}$ & & $\begin{array}{c}2.488 \\
(0.001)\end{array}$ & & $\begin{array}{c}2.121 \\
(0.067)\end{array}$ \\
\hline $\begin{array}{l}\text { Interaction (external dependence } \\
\text { x log[MARKET CAPITALIZATION] ) }\end{array}$ & & & $\begin{array}{c}2.074 \\
(0.001)\end{array}$ & $\begin{array}{c}0.889 \\
(0.142)\end{array}$ & & & $\begin{array}{c}1.973 \\
(0.001)\end{array}$ & $\begin{array}{c}0.768 \\
(0.252)\end{array}$ \\
\hline F-test joint significance & & & & $\begin{array}{c}18.63 \\
(0.001)\end{array}$ & & & & $\begin{array}{c}15.98 \\
(0.001)\end{array}$ \\
\hline Number of observations & 1380 & 1889 & 1380 & 1380 & 1380 & 1889 & 1380 & 1380 \\
\hline
\end{tabular}

All regressions include country and industry dummies

P-values from heteroskedasticty robust standard errors are reported in parentheses

All regressions are estimated using the English, French and German legal origin dummies as instrumental variables for the financial development indicators. In columns 4 and 8 the shares of Catholic, Muslim and Protestant population in total population are included as additional instrumental variables.

The F-test is for the joint significance of both interaction terms of external dependence with PRIVATE CREDIT and MARKET CAPITALIZATION.

Export share $=$ share of an industry's exports in GDP

Trade balance $=$ ratio of an industry's trade balance to GDP

External dependence = share of capital expenditures not financed with internal funds for U.S. firms in the same industry between 1970-80. Source: Rajan and Zingales (1998). PRIVATE CREDIT = credit by deposit money banks and other financial institutions to the private sector divided by GDP, times 100 .

MARKET CAPITALIZATION = value of listed domestic shares on domestic exchanges divided by GDP, times 100 .

TOTAL CAPITALIZATION = PRIVATE CREDIT + MARKET CAPITALIZATION 
Table 8: Industry Exports and Trade Balances and Financial Development External Dependence measured using Canadian firms

\begin{tabular}{|c|c|c|c|c|c|c|c|c|}
\hline Dependent variable & Export share & Export share & Export share & Export share & Trade balance & Trade balance & Trade balance & Trade balance \\
\hline $\begin{array}{l}\text { Interaction (external dependence } \\
\mathrm{x} \text { log[TOTAL CAPITALIZATION] ) }\end{array}$ & $\begin{array}{c}0.357 \\
(0.018)\end{array}$ & & & & $\begin{array}{c}0.359 \\
(0.017)\end{array}$ & & & \\
\hline $\begin{array}{l}\text { Interaction (external dependence } \\
x \text { log[PRIVATE CREDIT] ) }\end{array}$ & & $\begin{array}{c}0.359 \\
(0.011)\end{array}$ & & $\begin{array}{c}0.391 \\
(0.175)\end{array}$ & & $\begin{array}{c}0.394 \\
(0.004)\end{array}$ & & $\begin{array}{c}0.529 \\
(0.087)\end{array}$ \\
\hline $\begin{array}{l}\text { Interaction (external dependence } \\
\text { x log[MARKET CAPITALIZATION] ) }\end{array}$ & & & $\begin{array}{c}0.216 \\
(0.035)\end{array}$ & $\begin{array}{l}-0.047 \\
(0.772)\end{array}$ & & & $\begin{array}{c}0.209 \\
(0.037)\end{array}$ & $\begin{array}{l}-0.132 \\
(0.455)\end{array}$ \\
\hline F-test joint significance & & & & $\begin{array}{c}2.81 \\
(0.061)\end{array}$ & & & & $\begin{array}{c}2.88 \\
(0.057)\end{array}$ \\
\hline Number of observations & 1065 & 1456 & 1065 & 1065 & 1065 & 1456 & 1065 & 1065 \\
\hline
\end{tabular}

All regressions include country and industry dummies

P-values from heteroskedasticty robust standard errors are reported in parentheses

All regressions are estimated using the English, French and German legal origin dummies as instrumental variables for the financial development

indicators. In columns 4 and 8 the shares of Catholic, Muslim and Protestant population in total population are included as additional instrumental variables.

The F-test is for the joint significance of both interaction terms of external dependence with PRIVATE CREDIT and MARKET CAPITALIZATION.

Export share $=$ share of an industry's exports in GDP

Trade balance $=$ ratio of an industry's trade balance to GDP

External dependence $=$ share of capital expenditures not financed with internal funds for Canadian firms in the same industry between 1980-90. Source: Rajan and Zingales (1998).

PRIVATE CREDIT = credit by deposit money banks and other financial institutions to the private sector divided by GDP, times 100

MARKET CAPITALIZATION = value of listed domestic shares on domestic exchanges divided by GDP, times 100 .

TOTAL CAPITALIZATION = PRIVATE CREDIT + MARKET CAPITALIZATION 